УДК 378.(4:6)+001

Мінгальова Юлія Ігорівна

асистентка кафедри комп'ютерних наук та інформаційних технологій

Житомирський державний університет імені Івана Франка, м. Житомир, Україна

ORCID ID 0000-0003-1706-2673

mingalyovay@gmail.com

\title{
ВИКОРИСТАННЯ ІНФОРМАЦІЙНО-КОМУНІКАЦІЙНИХ ТЕХНОЛОГІЙ ДЛЯ ОРГАНІЗАЦІЇ НАУКОВО-ДОСЛІДНОЇ РОБОТИ МАЙБУТНІХ УЧИТЕЛІВ ІНФОРМАТИКИ
}

\begin{abstract}
Анотація. Стаття присвячена визначенню рівнів сформованості компетентності 3 використання інформаційно-комунікаційних технологій (ІКТ) для здійснення організації науково-дослідної роботи майбутніми вчителями інформатики на формувальному етапі педагогічного експерименту. Належний рівень досліджуваної компетентності може значно покращити організацію науково-дослідної роботи майбутніх учителів інформатики, сприяти науковому розвитку здобувача вищої освіти та його адаптації до освітніх технологічних змін. Аналіз наявних інформаційно-комунікаційних технологій дозволив виокремити такі типи засобів для організації науково-дослідної роботи майбутніх учителів інформатики: засоби пошуку, збереження та розміщення наукових матеріалів; засоби ІКТ для спільної роботи; засоби IКТ для перевірки матеріалів виконаних наукових робіт; засоби перевірки програмного коду на плагіат; засоби IКТ для підтримки ведення експериментальної наукової діяльності; засоби ІКТ для створення демонстраційного матеріалу. Сформульовано характеристики IКТ для здійснення організації науково-дослідної роботи: індивідуалізація наукової роботи; оптимізація пошукової діяльності; створення науковим керівником власного електронного курсу та інші. Завдяки проведеному науковому аналіз літератури визначено форми та етапи науково-дослідної роботи. У роботі представлено визначення поняття «компетентності 3 використання інформаційно-комунікаційних технологій для здійснення організації науково-дослідної роботи майбутніх учителів інформатики». Запропоновано авторську методику, що сприяє підвищенню рівня сформованості компетентності $з$ використання інформаційно-комунікаційних технологій для здійснення організації науково-дослідної роботи майбутніх учителів інформатики. У ході дослідження визначено критерії (мотиваційний, діяльнісно-когнітивний, адаптивно-рефлексивний) оцінювання рівня сформованості компетентності 3 IКТ для здійснення організації науково-дослідної роботи майбутніх учителів інформатики та її показники. Вказано рівні (елементарний, базовий, достатній, високий) та показники сформованості досліджуваної компетентності. Результати проведеного педагогічного експерименту підтвердили результативність авторської методики. Окреслено наступні напрямки наукових розвідок 3 представленої проблеми.
\end{abstract}

Ключові слова: науково-дослідна робота; здобувач вищої освіти; майбутній учитель інформатики; інформаційно-комунікаційні технології; ІКТ-компетентність.

\section{1. ВСТУП}

В Україні відбуваються значні економічні та соціальні реформи, які значною мірою впливають на формування нових вимог до майбутніх фахівців у сфері освіти. Відповідних змін зазнають вимоги до їх підготовки, однією з яких є вимога розвитку творчого та ініціативного спеціаліста, який матиме організаторські навички та вміння спрямовувати діяльність (власну та/або очолюваної групи) на вдосконалення процесу шляхом запровадження у практику нових досягнень науки й техніки. Втілення цієї вимоги в життя потребує широкого залучення здобувачів вищої освіти до наукової діяльності, залучення їх до науково-дослідної роботи закладу вищої освіти. Реалізація диференційованого підходу до організації науково-дослідної роботи здобувачів вищої 
освіти передбачає використання інформаційно-комунікаційних технологій. Вони надають студентам доступ до нових джерел інформації, інтенсифікують пізнавальну діяльність, сприяють формуванню навичок грамотного усного та писемного наукового спілкування.

Постановка проблеми. Інтеграція системи освіти України до європейського освітнього простору окреслює нові виклики та завдання, серед яких забезпечення якості вищої освіти є одним з ключових і становить необхідну умову руху української освіти до світових стандартів. У межах Болонського процесу забезпечення якості вищої освіти декларується як найважливіший орієнтир політики європейських держав у сфері освіти. В основоположному документі «Всесвітня декларація про вищу освіту для XXI століття: підходи і практичні заходи» зазначено, що на порозі XXI століття $\epsilon$ усвідомлення вирішального значення попиту на вищу освіту для соціально-культурного й економічного розвитку, створення такого майбутнього, у якому молодші покоління повинні будуть опановувати нові навички, знання та ідеї [1]. Окрім того, у Національній стратегії розвитку освіти в Україні на період до 2021 року зазначено, що «розбудова національної системи освіти в сучасних умовах 3 урахуванням кардинальних змін у всіх сферах суспільного життя, історичних викликів XXI століття вимагає критичного осмислення досягнутого і зосередження зусиль та ресурсів на розв'язанні найбільш гострих проблем, які стримують розвиток, не дають можливості забезпечити нову якість освіти, адекватну нинішній історичній епосі» [2].

Європейською комісією було висвітлено міжнародний документ "Open Science" (“Відкрита наука"), у якому було зазначено п’ять головних пріоритетів відкритої науки: доступ, дані, методи, освіта й оцінювання [3]. До принципів відкритої науки варто додати: відкритість методики і методів збирання та представлення даних під час дослідження; відкритий доступ до отриманих результатів з можливістю використання й надалі; відкритість процесів наукової комунікації; використання засобів ІКТ у ході наукового співробітництва і організації спільного доступу до даних [3].

Аналіз останніх досліджень і публікацій.

В. Биков, С. Вернигора, А. Гуржій, Л. Новохатько, О. Спірін, М. Шишкіна у своїх працях визначають поняттєво-термінологічний апарат формування хмаро орієнтованого освітньо-наукового середовища закладу вищої освіти та висвітлюють досвід експериментальних досліджень впровадження і використання окремих сервісів цього середовища в ході навчання і підготовки наукових та науково-педагогічних кадрів[4], [5].

Стан впровадження інструментів ІКТ для відкритого навчання та досліджень у педагогічних системах вищої освіти висвітлюють В. Биков, Д. Мікуловський, О. Моравчик, С. Светський та М. Шишкіна [6]. Досліджуючи роль інформаційно-комунікаційних технологій у самоорганізації суб'єктів освітнього процесу Н. Мирончук зазначає, що інформаційні інструменти використовуються для пошуку інформації, передачі знань, забезпечення зворотного зв'язку, організації дистанційної роботи як способи представлення інформації [7]. У статті Б. Клімова (B. Klimova) описує шляхи ефективного впровадження ІКТ на факультеті інформатики та менеджменту в Чехії та як їх використання може допомогти студентам у досягненні результату [8].

Відповідно до визначення О. Спіріна, інформаційно-комунікаційна компетентність або ІКТ-компетентність - це підтверджена здатність особистості використовувати на практиці інформаційно-комунікаційні технології для задоволення власних індивідуальних потреб і розв'язування суспільно значущих задач у певній предметній галузі [9]. Дослідження зарубіжних учених К. Гастели (C. Gastelú), Г. Кізба (G. Kissb), А. Домінгеса (A. Domínguez) спрямоване на аналіз компетенції в галузі IКТ 
студентів Угорщини та Мексики свідчить про необхідність розвитку стратегії, яка сприятиме ефективному використанню комунікаційних технологій [10]. У статті М. Бирка, А. Сущенко та Т. Лукашів розглядають зміст ІКТ-компетентності майбутніх учителів математики та інформатики і долучають такі критерії: знання, уміння, навички, ціннісні орієнтації (мотиви, стимули, цінності, інтереси та прагнення (амбіції)) та якості особистості (здібності, нахили) [11]. Питання використання інституційного репозиторію у формуванні науково-дослідницької компетентності магістрів досліджують Н. Римар, Н. Шульська, Н. Матвійчук, Ю. Громик та Р. Зінчук [12]. Різні аспекти впровадження й використання ІКТ розглянуто в роботах зарубіжних дослідників Е. Овреліда (Е. Øvrelida), Б. Бугстада (B. Bygstada), Г. Томасен (G. Thomassen), В. Куадрініа (W. Quadrinia), С. Галпароліа (S. Galparolia), Д. Нуцера (D. Nuceraa), Л. Фумагалліа (L. Fumagallia), Е. Негрі (E. Negri) [13],[14].

Зважаючи на роботи дослідників А. Алексюк, С. Вітвицької, Н. Гавриш, П. Горкуненко, О. Дубасенюк, В. Єремеєва, І. Зязюна, О. Мартиненко, О. Микитюк, Н. Пузирьова, 3. Сазонова, В. Шейко та інших представлено різні аспекти науково-дослідної роботи студентів у закладах вищої освіти; численні публікації вітчизняних i зарубіжних науковців стосуються теоретичних i практичних основ застосування інформаційно-комунікаційних технологій у ході навчання (В.Биков, В. Бобрицької, М. Жалдак, С. Литвинової, Ю. Машбиць, Н. Морзе, Ю. Носенко, О. Овчарук, О. Пінчук, Ю. Рамський, С. Семеріков, О. Соколюк, Н. Сороко, О. Співаковського, О. Спірін, Ю. Триус, М. Шишкіної та інших), а також історико-педагогічних аспектів теорії та практики організації науково-дослідної роботи студентської молоді (О. Глузман, Т. Долговицька, Г. Кловак, В. Курило, С. Радіонова, Ф. Ратнер, О. Слепенкова, А. Циганкова та інших), недостатньо визначеною залишається проблема організації науково-дослідної роботи майбутніх учителів інформатики шляхом використання інформаційно-комунікаційних технологій.

Проведений аналіз науково-педагогічних джерел дає можливість стверджувати, що ряд інформаційно-комунікаційних технологій допомагають організовувати етапи науково-дослідної роботи майбутніх учителів інформатики у закладах вищої освіти. Дослідники вважають, що ключовим підходом до підвищення якості вищої освіти $€$ збалансоване співвідношення педагогічних та інформаційно-комунікаційних технологій.

В освітньо-професійних програмах за предметною спеціалізацією 014.09 Середня освіта (Інформатика) до програмних компетентностей зараховують здатності: застосовувати інформаційні та комунікаційні технології, реалізовувати інформаційну модель засобами інформаційно-комунікаційних технологій, здійснювати комп'ютерний експеримент, проводити дослідження на сучасному науковому рівні, до пошуку, оброблення та аналізу інформації з різних джерел, раціонально планувати, здійснювати та оформляти результати творчої діяльності [15], [16], [17]. Професійна підготовка майбутнього вчителя інформатики має бути реалізована як комплексний педагогічний процес, що враховує використання ІКТ для здобуття вищої освіти та підвищення ії якості як вирішального чинника формування рівня готовності фахівця для вирішення професійних та наукових завдань [18].

Як вказано у Національній доктрині розвитку освіти, одними 3 пріоритетних напрямків $\epsilon$ : «органічне поєднання освіти i науки, розвиток педагогічної та психологічної науки, дистанційної освіти; запровадження освітніх інновацій, інформаційних технологій; інтеграція вітчизняної освіти до європейського та світового освітніх просторів» [19]. Відповідно до даного документу заклади вищої освіти мають забезпечити сприятливі умови для формування наукового світогляду, досягнення професіоналізму, розвитку творчого мислення та розширення теоретичного 
кругозору та наукової ерудиції студента. 3 огляду на вище зазначене, науково-дослідна діяльність студентів відіграє важливу роль у визначенні ефективності професійної підготовки майбутнього фахівця.

У попередніх роботах автором статті розглянуто інформаційно-комунікаційні технології як один із засобів реалізації науково-дослідної діяльності студентів [20], принципи використання гнучкого управління проєктами Scrum у науково-дослідній роботі студентів [21], організацію студентської науково-дослідної діяльності на заняттях 3 дисципліни «Основи наукових досліджень»[22] та використання сервісі Google для підтримки та супроводу студентської наукової діяльності[23].

Аналіз можливостей IКТ для організації науково-дослідної роботи майбутніх учителів інформатики, виокремлення їх переваг і недоліків зумовлює необхідність підтвердження ефективності розробленої авторської методики.

Метою статті $\epsilon$ оприлюднення результатів формувального етапу педагогічного експерименту щодо визначення рівнів сформованості компетентності з використання інформаційно-комунікаційних технологій для здійснення організації науково-дослідної роботи майбутніх учителів інформатики.

\section{2. РЕЗУЛЬТАТИ ДОСЛІДЖЕННЯ}

Науково-освітні інформаційні мережі забезпечують інформаційну підтримку освіти й науки та використовують інформаційно-комунікаційну платформу для підтримки передачі та спільного використання ресурсів. За допомогою технічних засобів, спеціальних видань, інформаційних мереж відкритого навчального середовища розповсюджується науково-педагогічна інформація (НПІ), як зазначає В. Ю. Биков, що використовується для організації навчально-виховного процесу, наукової діяльності [20]. Дослідники В. Ю. Биков, О.М.Спірін, М. П. Шишкіна виділяють такі функцій систем НПІ: вивчення потреб та формування нових дослідження; координація науково-дослідних робіт; вивчення та розповсюдження сучасного педагогічного досвіду; акумулювання та опрацювання документів щодо освітньої практики. Учені зараховують корпоративні інформаційні системи підтримування науково-освітньої діяльності до систем науково-педагогічної інформації [25].

Підтримка науково-дослідних робіт налічує ряд застосунків та платформ хмарних обчислень для забезпечення швидкого обміну даними, підтримки колективного використання ресурсів і матеріалів та налагодження комунікації в межах проєкту, спільного створення та поширення знань у наукових співтовариствах. У проєкті HORISON 2020 також зазначено, що IКT-сервіси та засоби використовуються для проведення досліджень та підтримки наукового співробітництва [26]. Уточнення поняття дослідницької електронної інфраструктури знайшло своє відображення в міжнародних документах, де підкреслено високі вимоги до рівня послуг та їх відповідність вже існуючим науковим та технічним стандартам [27]. Зазначено, що дослідницькі інфраструктури - засоби, ресурси або сервіси виняткового характеру для проведення досліджень [27].

Аналіз наявних інформаційно-комунікаційних технологій, які доцільно використовувати при організації науково-дослідної роботи майбутніх учителів інформатики, дозволив виокремити такі типи засобів (рис.1):

А. Засоби пошуку, збереження та розміщення наукових матеріалів - системи пошуку наукових ресурсів та матеріалів в електронних мережах; сервіси розміщення матеріалів різного формату у вільному доступі в мережі Інтернет та ті, що слугують для збереження необхідних матеріалів для науково-дослідної роботи майбутнього вчителя інформатики на електронній сторінці тощо (наприклад, Google, Yandex, Bing; arXiv.org, 
Google Scholar, Research Gate, Sci-Hub, Social Science Research Network, Digital Bibliography \& Library Project, Public Library of Science, Scopus; Delicious, Bibsonomy, Zeto; YouTube, iTunes, Scribd, Flicker, SlideShare).

В. Засоби ІКТ для спільної роботи - системи співпраці молодих дослідників для редагування та створення контенту (collaboration editing), організації спільної роботи здобувачів вищої освіти та наукових керівників, 3 використанням яких майбутні вчителі інформатики можуть виконувати групові проєкти та реферативні роботи, готувати спільні доповіді, працювати 3 викладачем над курсовими та дипломними роботами; засоби організації спілкування суб'єктів науково-дослідної роботи за допомогою електронної пошти, відеоконференцій, обговорень, чату, оголошення; онлайн сховища матеріалів науково-дослідної роботи, за допомогою яких викладачі та майбутні вчителі інформатики завантажують файли з відповідним контентом різного формату (текстові, графічні, аудіо, відео тощо); сервіси забезпечення можливості спільного одночасного доступу до документів різних форматів і роботу з ними та ін. у мережі Інтернет; онлайн лекції, дистанційні курси, відеоконференції, онлайн презентації, організовані за допомогою webтехнологій (наприклад, Glogster, Dabbleboard, Wikiwall, Scribblar, Padlet; OpenMeetings, BigBlueButton, Adobe Connect Pro Meeting, EDU Conference, TeamViewer, Twitter, BigBlueButton, Mirapolis Virtual Room; Web 3.0, Skype, Windows Live; Facebook, Twitter, Linkedln, MySpace; Second Life, Academia.edu, ResearchGate).

C. Засоби IКТ для перевірки матеріалів виконаних наукових робіт - майбутні вчителі інформатики можуть використати засоби IКТ для перевірки правопису та дотримання вимог наукового стилю тексту наукової роботи, перекладу необхідних відомостей будь-якою мовою (наприклад, Promt, Google Translator; Advego Plagiatus, Etxt Antiplagiat;Online Corrector, LanguageTool, Advego, Poetica, Test-the-Text, Draft, HamingwayApp, типографська розкладка Іллі Бірмана (українська версія), Readability).

D. Засоби перевірки програмного коду на плагіат (наприклад, MOSS, JPlag, SIM, Sherlock (BOSS), PMD(CMD), CodeMatch);

Е. Засоби ІКТ для підтримки ведення експериментальної наукової діяльності підтримка ведення експериментальної наукової діяльності (збір, агрегація, опрацювання даних та відомостей) майбутніх учителів інформатики засобами IКТ, пошук та опрацювання статистичних відомостей для наукових досліджень; засоби підтримки проєктних робіт, майбутні вчителі інформатики можуть їх використовувати для відображення списку поставлених завдань для виконання проєкту (курсових i дипломних робіт, конференцій, олімпіад тощо), розкладу спільних зустрічей проблемних груп і консультацій з керівником наукової роботи (наприклад, пакет хмарних сервісів Google Workspace, Open Science Framework, QuizForce, WordForce, GoogleDocs, Spreadsheets, Gliffy (diagrams), GoogleWave, SharePoint, SPSS; GitHub).

F. Засоби IKT для створення демонстраційного матеріалу - засоби загального призначення, за допомогою яких можна створювати як динамічний, так і статичний демонстраційний матеріал, системи вебінтеграції та бриколажу, що уможливлюють форматування та змішування різних форматів представлення відомостей та даних i обробку вебсторінки з будь-яким рівнем знання мови HTML (наприклад, Del.icio.us, SkypeMe, PingMe services, Yahoo Pipes; Freemind, Coggle, Mindomo, MindMeister, XMind, Програма WiseMapping; Prezi.com, ZohoShow, SlideShare, Vcasmo, Camtasia, Snagit, Office Sway, EdPuzzle, Googleslides; Canva, Piktochart, Snagit, Spark for Education, Easel.ly, Infogram). 


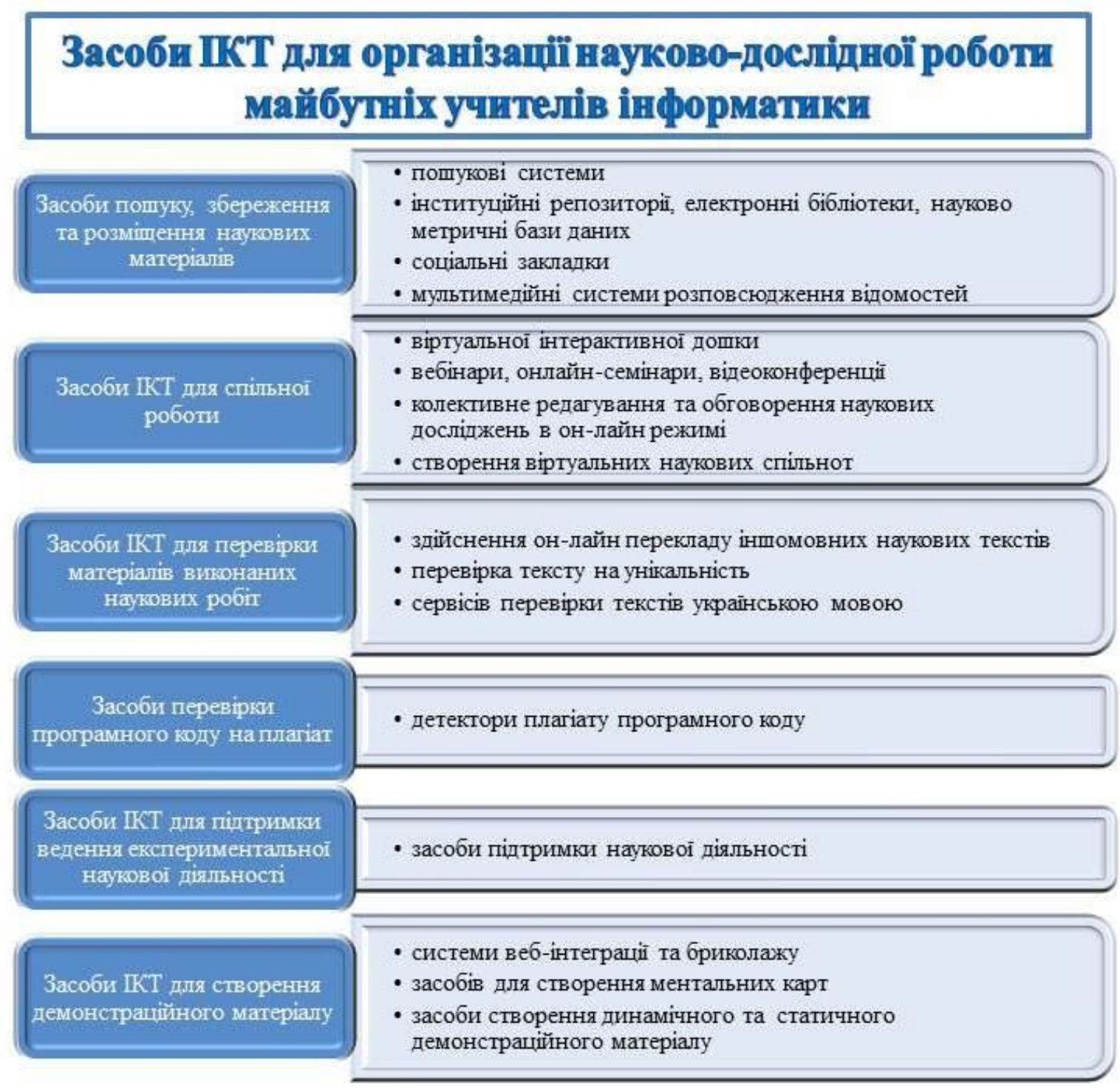

Рис. 1. Типи засобів інформаційно-комунікаційних технологій для організації науководослідної роботи майбутніх учителів інформатики

Було сформульовано характеристики IКТ, які доцільно використовувати в організації науково-дослідної роботи майбутніх учителів інформатики, а саме: індивідуалізація наукової роботи; підвищення ефективності пошукової діяльності; створення науковим керівником власного електронного курсу; швидке розповсюдження необхідного матеріалу; самостійне оцінювання наукової роботи майбутніми вчителями інформатики; різноманітність засобів комунікації суб'єктів науково-дослідної роботи; зручні засоби для співпраці тощо.

Визначено форми науково-дослідної роботи (навчально-дослідницька, що виконується згідно 3 навчальними планами під керівництвом професорсько-викладацького складу: реферування наукових видань, огляди нових літературних видань відповідно до напряму досліджень, проведення виступів 3 підготовленими доповідями та повідомленнями з елементами наукового дослідження, проведення наукових досліджень при написанні курсових i дипломних робіт, виконання науково-дослідних завдань під час навчальної практики та стажування; та науково-досліднцьку, яку виконують у позанавчальний час: робота у наукових 
товариствах, проблемних групах, участь у науково-дослідних роботах згідно теми кафедри, виступи на науково-теоретичних та науково-практичних конференціях, участь у внутрішніх та міжвузівських, регіональних та Всеукраїнських конкурсах та олімпіадах кращих наукових робіт, підготовка публікацій відповідно до проведених досліджень), етапи (підготовчо-цільовий - спрямований на ознайомлення 3 послідовністю та взаємозв'язком складових елементів дослідницької роботи у закладі вищої освіти, заохочення студентів ЗВО до науково-дослідної роботи, розширення їх наукового кругозору, мотивацію студентства до залучення до наукової діяльності, створення сприятливих умов для розвитку пошукового, пізнавального та дослідницького інтересу майбутніх фахівців, формування у них потреби наукового пошуку та професійного вдосконалення впродовж життя, процесуально-змістовий передбачає оволодіння студентами основних методів науково-дослідної роботи шляхом проведення індивідуальних консультацій, лекцій; підготовку до виконання науково-дослідної роботи за допомогою написання рефератів, наукових повідомлень; проведення диспутів, діалогів, співбесід; залучення студентів до пізнавальнодослідницької діяльності на семінарських та практичних заняттях; вибір теми курсової, бакалаврської чи магістерської роботи та іiї формулювання, осмислення й добирання фактичного наукового матеріалу з обраної проблеми, складання бібліографії; аналіз одержаного наукового матеріалу, проведення досліду, обробка, аналіз та узагальнення одержаних результатів роботи, формулювання висновків, оформлення рукопису роботи згідно з чинними вимогами; участь у роботі наукових гуртків, проблемних груп, інших формах науково-дослідної роботи майбутніх учителів інформатики, досвідно-результативний - полягає в отриманні досвіду оформлення тексту доповіді та ілюстративного матеріалу, підготовці та налагодженні макетів, моделей, приладів тощо для демонстрації власної наукової роботи у вигляді публічного виступу, апробації результатів на конференціях, форумах, симпозіумах; участь в олімпіадах, конкурсах, грантах; участь в освітніх, виробничих чи наукових проєктах).

Компетентність 3 використання інформаційно-комунікаційних технологій для здійснення організації науково-дослідної роботи майбутніх учителів інформатики визначаємо як підтверджену на практиці здатність особистості на основі опанованих знань, умінь та навичок з ІКТ використовувати такі засоби для організації власної науково-дослідної роботи.

Для визначених критеріїв оцінювання рівня сформованості компетентності 3 використання інформаційно-комунікаційних технологій для здійснення організації науково-дослідної роботи майбутніх учителів інформатики нами було визначено ряд відповідних показників, які подано у таблиці 1.

Таблиия 1

Критерії та показники оцінювання рівня сформованості компетентності 3 використання інформаційно-комунікаційних технологій для здійснення організації науково-дослідної роботи майбутніх учителів інформатики

\begin{tabular}{|c|ll|}
\hline \multicolumn{1}{|c|}{ Критерій } & \multicolumn{1}{c|}{ Показники } \\
\hline \multirow{3}{*}{ Мотиваційний критерій } & $1)$ & мотивація до використання ІКТ; \\
& $2)$ & мотивація досягнення успіху в науковій діяльності; \\
& $3)$ & мотивація до самонавчання. \\
\hline
\end{tabular}




\begin{tabular}{|c|c|}
\hline $\begin{array}{l}\text { Діяльнісно-когнітивний } \\
\text { критерій }\end{array}$ & 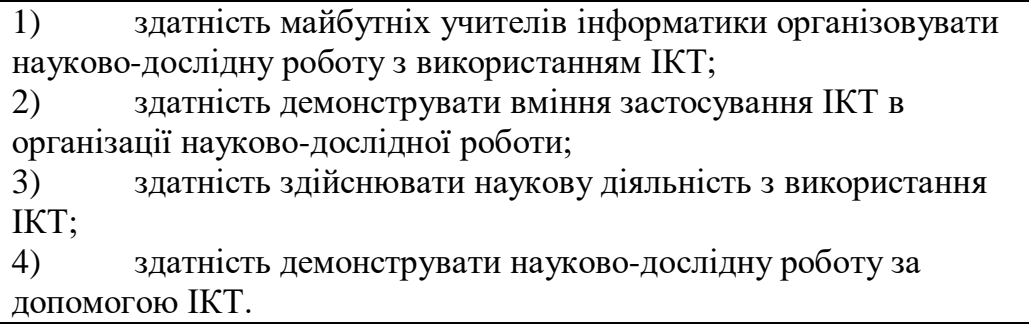 \\
\hline $\begin{array}{l}\text { Адаптивно-рефлексивний } \\
\text { критерій }\end{array}$ & 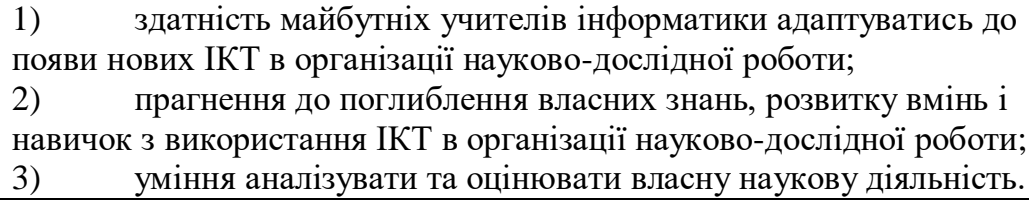 \\
\hline
\end{tabular}

Рівні сформованості компетентності 3 використання інформаційно-комунікаційних технологій для здійснення організації науково-дослідної роботи майбутніх учителів інформатики та показники для кожного з них представлено в таблиці 2.

Таблиия 2

Рівні та показники сформованості компетентності з використання інформаційно-комунікаційних технологій для здійснення організації науково-дослідної роботи майбутніх учителів інформатики

\begin{tabular}{|c|c|}
\hline Рівень сформованості & Показники сформованості \\
\hline Елементарний & $\begin{array}{l}\text { Володіє елементарними прийомами роботи з ІКТ. } \\
\text { За допомогою викладача відтворює отримані знання; } \\
\text { неповно характеризує окремі поняття науково-дослідної } \\
\text { роботи; відтворює незначну частину пошукової } \\
\text { діяльності; відсутня мотивація до наукової діяльності; } \\
\text { байдуже та формально ставиться до організації власної } \\
\text { науково-дослідної роботи. }\end{array}$ \\
\hline Базовий & $\begin{array}{l}\text { Уміє використовувати основні засоби ІКТ. } \\
\text { Фрагментарно володіє знаннями } 3 \text { організації } \\
\text { науково-дослідної роботи за допомогою ІКТ; розуміє та } \\
\text { може організувати певні етапи науково-дослідної } \\
\text { роботи; має слабку мотивацію до наукової діяльності; у } \\
\text { мисленні окреслюється перехід від репродуктивних до } \\
\text { пошукових форм. }\end{array}$ \\
\hline Достатній & $\begin{array}{l}\text { Уміє використовувати більшу частину засобів ІКТ. } \\
\text { Набув основних знань, умінь і навичок з організації } \\
\text { науково-дослідної роботи за допомогою ІКТ; розуміє та } \\
\text { може пояснити етапи організації науково-дослідної } \\
\text { роботи; наводить власні приклади застосування IКТ; } \\
\text { мотивований до наукової діяльності. }\end{array}$ \\
\hline Високий & $\begin{array}{l}\text { Уміє використовувати весь функціонал ІКТ. Має } \\
\text { грунтовні теоретичні знання та практичні вміння } \\
\text { використання ІКТ в організації науково-дослідної } \\
\text { роботи; аргументовано висловлює власні думк; } \\
\text { реалізує самостійну наукову діяльність; проявляє творчу } \\
\text { самостійну активність і креативність при організації } \\
\text { науково-дослідної роботи. }\end{array}$ \\
\hline
\end{tabular}


Для перевірки ефективності авторської методики експериментальне дослідження проводилось упродовж 2014-2019 років на базі Житомирського державного університету імені Івана Франка.

Експериментальним дослідженням було охоплено 162 майбутніх учителя інформатики Житомирського державного університету імені Івана Франка, з них: 80 учасники експериментальної групи (ЕГ) і 82 - контрольної групи (КГ).

У ході проведення педагогічного експерименту було забезпечено дотримання основних вимог щодо застосування статистичних методів опрацювання результатів дослідження, зокрема однорідність та незалежність вибірок та випадковий характер вибірок. Опрацювання результатів здійснювалось 3 використанням t-критерію Стьюдента та $\chi^{2}$ критерія Пірсона. Статистичне опрацювання засвідчило однорідність вибірок на початку експерименту та статистично значущі відмінності між ними наприкінці експерименту. Діаграма порівняльного розподілу студентів у КГ та ЕГ за рівнями сформованості досліджуваної компетентності за результатами констатувального та кінцевого зрізів представлена на рисунку 2.

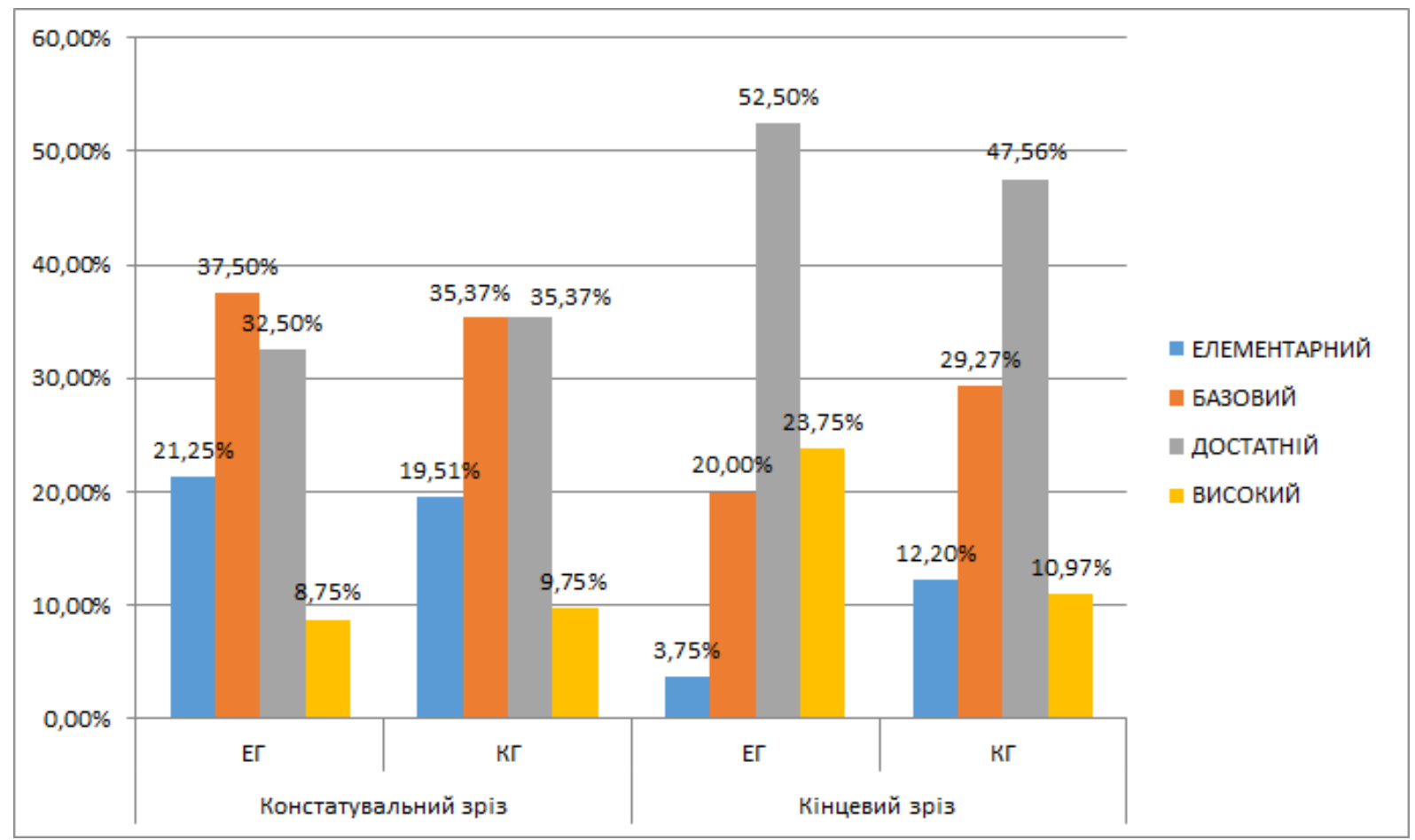

Рис. 2. Діаграма порівняльного розподілу студентів у КГ та ЕГ за рівнями сформованості досліджуваної компетентності за результатами констатувального та кінцевого зрізів

Гіпотеза, підтверджена статистичними розрахунками і застосуванням авторської методики розвитку компетентності 3 використання інформаційно-комунікаційних технологій для здійснення організації науково-дослідної роботи майбутніми вчителями інформатики, забезпечує кращий результат, оскільки значно більше майбутніх учителів інформатики експериментальної групи порівняно 3 кількістю студентів контрольної групи підвищили свій рівень досліджуваної компетентності. 


\section{3. ВИСНОВКИ ТА ПЕРСПЕКТИВИ ПОДАЛЬШИХ ДОСЛІДЖЕНЬ}

Аналіз наявних інформаційно-комунікаційних технологій дозволив виокремити такі типи засобів для організації науково-дослідної роботи майбутніх учителів інформатики: засоби пошуку, збереження та розміщення наукових матеріалів; засоби IКТ для спільної роботи; засоби ІКТ для перевірки матеріалів виконаних наукових робіт; засоби перевірки програмного коду на плагіат; засоби IКТ для підтримки ведення експериментальної наукової діяльності; засоби ІКТ для створення демонстраційного матеріалу. Аналізуючи можливості IКТ, виокремлено їх переваги для здійснення організації науково-дослідної роботи: індивідуалізація наукової роботи; оптимізація пошукової діяльності; створення науковим керівником власного електронного курсу та інші. Завдяки проведеному науковому аналіз літератури визначено форми (навчально-дослідницьку, науково-дослідницьку) та етапи науково-дослідної роботи (підготовчо-цільовий, процесуально-змістовий, досвідно-результативний). Впровадження інформаційно-комунікаційних технологій у науково-дослідну роботу закладів вищої освіти України сприяє підвищенню рівня конкурентноспроможності останніх на міжнародному ринку освітніх послуг. Результати порівняльного аналізу даних початкового і підсумкового зрізів та використання методів математичної статистики (критерій Пірсона) підтвердили позитивну динаміку розвитку ІКТкомпетентності майбутніх учителів інформатики щодо використання інформаційнокомунікаційних технологій в організації науково-дослідної роботи за авторською методикою, що дозволяє зробити висновок про іiї ефективність. Отже, здобувачі вищої освіти успішно формують та підвищують рівень власної компетентності 3 використання ІКТ для організації науково-дослідної роботи використовуючи дану методику. Основою для реалізації даної методики в освітньому процесі закладів вищої освіти $\epsilon$ викладання навчального предмету «Основи наукових досліджень», що передбачений навчальним планом для студентів першого (бакалаврського) рівня спеціальності 014.09 Середня освіта (Інформатика), у здобувачів вищої освіти $\epsilon$ можливість практичного використання дібраних ІКТ для організації науково-дослідної роботи. Перспективами для вивчення залишаються питання пошуку шляхів підвищення зацікавленості студентів до проведення наукової роботи та виявлення теоретико-методичних основ інтеграції ІКТ у науково-дослідну діяльність студентів 3ВО. Науковий пошук варто продовжити у таких напрямах: підвищення кваліфікації вчителів інформатики та викладачів дисциплін 3 використанням IКТ в організації науково-дослідної роботи, а також удосконалення навчальних i робочих програм дисципліни «Інформаційно-комунікаційні технології в наукових дослідженнях» у підготовці магістрів педагогічних спеціальностей.

\section{СПИСОК ВИКОРИСТАНИХ ДЖЕРЕЛ}

[1] World declaration on higher education for the twenty-first century: vision and action. URL: http://www.unesco.org/education/educprog/wche/ declaration_eng.htm.

[2] Національна стратегія розвитку освіти в Україні на період до 2021 року. [Електронний ресурс]. Доступно: https://hoippo.km.ua/ news-view-156.html.

[3] K. Mayer, «Open Science Policy Briefing,» ERA Austria, 2019.

[4] В.Ю. Биков, С.М. Вернигора, А.М. Гуржій, Л.М. Новохатько, .М. Спірін, М.П. Шишкіна, «Проєктування і використання відкритого хмаро орієнтованого освітньо-наукового середовища закладу вищої освіти», Інформащійні технології $i$ засоби навчання, №6 (74), 2019. [Електронний pесурс]. Доступно: https://journal.iitta.gov.ua/index.php/itlt/article/view/3499/1585.

[5] V. Bykov, M. Shyshkina, «The Conceptual Basis of the University Cloud-based Learning and Research Environment Formation and Development in View of the Open Science Priorities», Information Technologies 
$\begin{array}{lllll}\text { and } \quad \text { Learning } & \text { Tools, } & \text { Vol.68(6), } & \text { P.1-19, } & 2018 .\end{array}$ URL: https://journal.iitta.gov.ua/index.php/itlt/article/view/2609/1409.

[6] V. Bykov, D. Mikulowski, O. Moravcik, S. Svetsky, M. Shyshkina, «The use of the cloud-based open learning and research platform for collaboration in virtual teams», Information Technologies and Learning Tools, vol.76(2). P.304-320, 2020. URL: https://journal.iitta.gov.ua/index.php/itlt/article/view/3706.

[7] Н.М. Мирончук, «Інформаційно-комунікаційні технології як засіб самоорганізації суб'єктів освітнього процесу», Інформаціийні технології $і$ засоби навчання, №1 (75), 2020. [Електронний ресурс]. Доступно: https://journal.iitta.gov.ua/index.php/itlt/article/view/2537/1629.

[8] B.F. Klimova, «Making academic writing real with ICT», Procedia Computer Science 3. P. 133-137, 2011.

[9] О.М. Спірін, «Інформаційно-комунікаційні та інформатичні компетентності як компоненти системи професійно-спеціалізованих компетентностей вчителя інформатики», Інформаційні технології $i$ засоби навчання, №5 (13), 2009. [Електронний Доступно: https://journal.iitta.gov.ua/index.php/itlt/article/view/183/169.

[10] C. A. T. Gastelú, G. Kissb, A. L. Domínguez, «Level of ict competencies at the university», Procedia - Social and Behavioral Sciences 174. P. 137-142, 2015.

[11] M.F. Byrka, A.V. Sushchenko; T.O. Lukashiv, «Components of ICT competence of teachers of mathematics and informatics», Information Technologies and Learning Tools, vol.74(6), P. 225-237, 2019. URL: https://journal.iitta.gov.ua/index.php/itlt/article/view/3258/1588.

[12] Н.Ю. Римар, Н.М. Шульська, Н.М. Матвійчук, Ю.В. Громик, та Р.С. Зінчук, «Використання інституційного репозиторію для формування науково-дослідницької компетентності», Інформаційні технології $i$ засоби навчання, №2 (76), 2020. [Електронний ресурс]. Доступно: https://journal.iitta.gov.ua/index.php/itlt/article/view/2753/1650.

[13] E. Øvrelida, B. Bygstada, G. Thomassen, «TSD: A Research Platform for Sensitive Data», Procedia Computer Science 181. P. 127-134, 2021.

[14] W. Quadrinia, S. Galparolia, D. D. Nuceraa, L. Fumagallia, E. Negri, «Architecture for Data Acquisition in Research and Teaching Laboratories», Procedia Computer Science 180. P. 833-842, 2021.

[15] Освітньо-професійна програма «Середня освіта (Інформатика)» першого (бакалаврського) рівня вищої освіти за спеціальністю 014 Середня освіта предметної спеціальності 014.09 Середня освіта (Інформатика) галузі знань 01 Освіта/Педагогіка. Запоріжжя, 2020. [Електронний ресурс]. Доступно: https://www.znu.edu.ua/opp2020/bak/math/op_014_09_serednya_osv_ta_nform_.pdf

[16] Освітньо-професійна програма «Середня освіта: Інформатика» першого рівня вищої освіти на здобуття освітнього ступеня бакалавра за спеціальністю 014 Середня освіта предметною спеціалізацією 014.09 Інформатика галузі знань 01 Освіта/Педагогіка. Ізмаїл, 2017. [Електронний ресурс]. Доступно: http://idgu.edu.ua/wp-content/uploads/2018/07/osv.prohr.inform_2017-nova-2.pdf

[17] Освітньо-професійна програма 014.09 Середня освіта (Інформатика) рівень вищої освіти перший (бакалаврський) ступінь вищої освіти бакалавр спеціальнісь 014 Середня освіта предметна спеціалізація 014.09 Середня освіта (Інформатика). Рівне, 2019. [Електронний ресурс]. Доступно: http://rshu.edu.ua/images/osvitni_programi/osv_prog_bak_014_so_informatika_2019.pdf

[18] А.А. Харківська, «Підвищення якості вищої педагогічної освіти через використання новітніх інформаційних технологій», Проблеми інженерно-педагогічної освіти, № 37, С. 46-50, 2012.

[19] Національна доктрина розвитку освіти. [Електронний Доступно: http://zakon4.rada.gov.ua/laws/show/347/2002.

[20] Ю.І. Мінгальова, «Інформаційно-комунікаційні технології як один із засобів реалізації науково-дослідної діяльності студентів фізико-математичних факультетів», Наукові записки Бердянського державного педагогічного університету, Серія: Педагогічні науки, вип. 1, С 171-177, 2018.

[21] Ю.І. Мінгальова, «Принципи використання гнучкого управління проектами Scrum в науково-дослідній роботі студентів», «нноваційна педагогіка», Випуск 7, том 2, Одеса: ПУ «Причорноморський науково-дослідний інститут економіки та інновацій», С. 79-82, 2018.

[22] Ю.І. Мінгальова, «Організація студентської науково-дослідної діяльності на заняттях із дисципліни «Основи наукових досліджень», Педагогіка формування творчої особи у вищій $і$ загальноосвітній школах: зб. наук. пр./ [редкол.: А.В. Сущенко (голов. ред.) та ін.], Запоріжжя: КПУ, Вип. 61, Т. 2, C. 126-131, 2018.

[23] Ю. І. Мінгальова, «Використання сервісі Google для підтримки та супроводу студентської наукової діяльності», Збірник наукових праць, Педагогічні науки/Випуск LXXXVIII, Xерсон: Херсонський державний університет, С. 115-119, 2019.

[24] В.Ю. Биков, В.В. Олійник, «Інформаційні мережі відкритого навчального середовища», Післядипломна освіта в Україні, №1, С. 54-63, 2008.

[25] В.Ю. Биков, О.М. Спірін, М.П. Шишкіна, «Корпоративні інформаційні системи підтримування науково-освітньої діяльності на базі хмаро орієнтованих сервісів», Проблеми та перспективи 
формування національної гуманітарно-технічної еліти : Зб. наук. праць / за ред. Л.Л. Товажнянського, О.Г. Романовського, Вип. 43, Ч. 2, Харків : НТУ «ХПІ», С. 93-121, 2015.

[26] Digital science in Horizon 2020, DG Connect, 7 March 2013, 30 p.

[27] Strategy Report on Research Infrastructures. Roadmap 2010, Luxembourg: Publication Office of the European Union, 80 p, 2011.

Матеріал надійшов до редакиї 11.08 .2020 р.

\title{
ИСПОЛЬЗОВАНИЕ ИНФОРМАЦИОННО-КОМУНИКАЦИОННЫХ ТЕХНОЛОГИЙ ДЛЯ ОРГАНИЗАЦИИ НАУЧНО-ИССЛЕДОВАТИЛЬСКОЙ РАБОТЫ БУДУЩИХ УЧИТЕЛЕЙ ИНФОРМАТИКИ
}

\author{
Мингалёва Юлия Игоревна \\ ассистентка кафедры компьютерных наук и информационных технологий \\ Житомирский государственный университет имени Ивана Франко, г. Житомир, Украина \\ ORCID ID 0000-0003-1706-2673 \\ mingalyovay@gmail.com
}

\begin{abstract}
Аннотация. Статья посвящена определению уровней формирования компетентности по использованию информационно-коммуникационных технологий (ИКТ) для осуществления организации научно-исследовательской работы (НИР) будущих учителей информатики на заключительном этапе педагогического эксперимента. Надлежащий уровень исследуемой компетентности может значительно улучшить организацию НИР будущих учителей информатики, способствовать научному развитию соискателя высшего образования и его адаптации к образовательным технологическим изменениям. Анализ имеющихся ИКТ позволил выделить следующие типы средств для организации НИР будущих учителей информатики: средства поиска, хранения и размещения научных материалов; средства ИКТ для совместной работы; средства ИКТ для проверки материалов выполненных научных работ; средства проверки кода на плагиат; средства ИКТ для поддержки проведения экспериментальной научной деятельности; средства ИКТ для создания демонстрационного материала. Сформулированы характеристики ИКТ для осуществления организации НИР: индивидуализация научной работы; оптимизация поисковой деятельности; создание научным руководителем собственного электронного курса и другие. Благодаря проведенному научному анализу литературы определены формы и этапы НИР. В работе представлено определение понятия «компетентности по использованию информационно-коммуникационных технологий для осуществления организации научно-исследовательской работы будущих учителей информатики». Предложена авторская методика, которая способствует повышению уровня формирования компетентности по использованию ИКТ для осуществления организации НИР будущих учителей информатики. В процессе исследования определены критерии (мотивационный, действенно-когнитивный, адаптивно-рефлексивный) и показатели оценки уровня формирования компетентности с ИКТ для осуществления организации научно-исследовательской работы будущих учителей информатики. Указано уровни (элементарный, базовый, достаточный, высокий) и показатели формирования исследуемой компетентности. Результаты проведенного педагогического эксперимента подтвердили результативность авторской методики. Определены следующие направления научных исследований по представленной проблеме.
\end{abstract}

Ключевые слова: научно-исследовательская работа; соискатель высшего образования; будущий учитель информатики; информационно-коммуникационные технологии; ИКТ-компетентность.

\section{THE USE OF INFORMATION AND COMMUNICATION TECHNOLOGIES FOR ORGANIZATION OF RESEARCH WORK OF FUTURE COMPUTER SCIENCE TEACHERS}




\title{
Yuliia I. Minhalova
}

Assistant at the Department of Computer Science and Information Technology

Zhytomyr Ivan Franko State University, Zhytomyr, Ukraine

ORCID ID 0000-0003-1706-2673

mingalyovay@gmail.com

\begin{abstract}
The article is devoted to determining the levels of competence in the use of information and communication technologies (ICT) for the organization of future computer science teachers' research work at the final stage of the pedagogical experiment. The appropriate level of the investigated competence can significantly improve the future computer science teachers' research work arrangement and contribute to the student's scientific development and their adaptation to educational technological changes. The analysis of the available information and communication technologies makes it possible to identify the following types of means for the future computer science teachers' research work arrangement: means of searching, storage and placement of scientific materials; ICT tools for collaboration; ICT tools for materials verification of performed scientific works; means of checking software code for plagiarism; ICT tools to support experimental research activities; ICT tools to create demonstration material. The characteristics of ICT for the research work arrangement are formulated: individualization of scientific work; search activity optimization; creation of the electronic course by the scientific supervisor, etc. The conducted scientific analysis of the literature the forms and stages of research work have been determined. The paper presents the definition of "competence in the use of information and communication technologies for the research work arrangement of future computer science teachers". It is presented the author's methodology which contributes to increase the level of formation of competence in the use of ICT for the organization of research work of future computer science teachers. In the course of the research, the criteria (motivational, effectivecognitive, adaptive-reflexive) and indicators for assessing the level of formation of competence with ICT for the organization of research work of future computer science teachers were determined. The levels (elementary, basic, sufficient, high) and indicators of formation of the studied competence are specified. The results of the conducted pedagogical experiment confirmed the effectiveness of the author's methodology. The following directions of scientific research on the presented problem have been identified.
\end{abstract}

Keywords: research work; applicant for higher education; future computer science teacher; information and communication technologies; ICT-competence.

\section{REFERENCES (TRANSLATED AND TRANSLITERATED)}

[1] World declaration on higher education for the twenty-first century: vision and action. [Online]. Available: http://www.unesco.org/education/educprog/wche/ declaration_eng.htm (in English).

[2] National strategy for the development of education in Ukraine until 2021. [Online]. Available: https://hoippo.km.ua/news-view-156.html (in Ukrainian).

[3] K. Mayer, «Open Science Policy Briefing» ERA Austria, 2019 (in English).

[4] V. Yu. Bykov, S. M. Vernygora, A. M. Hurzhii, L. M. Novohatko, O. M. Spirin, M. P. Shyshkina, «The design and use the open cloud based learning and research environment of a university», Information Technologies $\begin{array}{lllll}\text { and Learning } & \text { Tools, } & \text { vol.74(6), } & \text { pp.19, } & \text { [Online]. }\end{array}$ Available: https://journal.iitta.gov.ua/index.php/itlt/article/view/3499/1585 (in Ukrainian).

[5] V. Bykov, M. Shyshkina, «The Conceptual Basis of the University Cloud-based Learning and Research Environment Formation and Development in View of the Open Science Priorities», Information Technologies and Learning Tools, vol.68(6), pp.1-19, $2018 . \quad$ [Online]. Available: https://journal.iitta.gov.ua/index.php/itlt/article/view/2609/1409 (in English).

[6] V. Bykov, D. Mikulowski, O. Moravcik, S. Svetsky, M. Shyshkina, «The use of the cloud-based open learning and research platform for collaboration in virtual teams», Information Technologies and Learning Tools, vol.76(2). pp.304-320, 2020. [Online]. Available: https://journal.iitta.gov.ua/index.php/itlt/article/view/3706 (in English).

[7] N.M. Myronchuk, «Information and communication technologies as a means for the educational process actors' self-organization», Information Technologies and Learning Tools, vol.75(1), pp. 202-211, 2020. [Online]. Available: https://journal.iitta.gov.ua/index.php/itlt/article/view/2537/1629 (in Ukrainian).

[8] B.F. Klimova, «Making academic writing real with ICT», Procedia Computer Science 3. pp. 133-137, 2011 (in English). 
[9] O. M. Spirin, «Information and communication competencies as components of the system of professional-specialized competences of the teacher of informatics», Information Technologies and Learning Tools, no.5 (13), 2009. [Online]. Available: https://journal.iitta.gov.ua/index.php/itlt/article/view/183/169 (in Ukrainian).

[10] C. A. T. Gastelú, G. Kissb, A. L. Domínguez, «Level of ict competencies at the university», Procedia - Social and Behavioral Sciences 174. pp. 137-142, 2015 (in English).

[11] M.F. Byrka, A.V. Sushchenko; T.O. Lukashiv, «Components of ICT competence of teachers of mathematics and informatics», Information Technologies and Learning Tools, vol.74(6), pp. 225-237, 2019. [Online]. Available: https://journal.iitta.gov.ua/index.php/itlt/article/view/3258/1588 (in English).

[12] N. Yu. Rymar, N. M. Shulska, N. M. Matviichuk, Yu. V. Hromyk, R. S. Zinchuk «The use of institutional repository for the formation of master students` research competence», Information Technologies and Learning $\begin{array}{llll}\text { Tools, } & \text { vol.76(2), } & \text { pp. 198-212, } & 2020 .\end{array}$ Available: https://journal.iitta.gov.ua/index.php/itlt/article/view/2753/1650 (in Ukrainian).

[13] E. Øvrelida, B. Bygstada, G. Thomassen, «TSD: A Research Platform for Sensitive Data», Procedia Computer Science 181. pp. 127-134, 2021(in English).

[14] W. Quadrinia, S. Galparolia, D. D. Nuceraa, L. Fumagallia, E. Negri, «Architecture for Data Acquisition in Research and Teaching Laboratories», Procedia Computer Science 180. pp. 833-842, 2021(in English).

[15] Educational-professional program "Secondary education (Computer Science)" of the first (bachelor's) level of higher education in the specialty 014 Secondary education of the subject specialty 014.09 Secondary education (Computer Science) in the field of knowledge 01 Education/Pedagogy. Zaporizhzhia, 2020. [Online]. Available: https://www.znu.edu.ua/opp2020/bak/math/op_014_09_serednya_osv_ta__nform_.pdf (in Ukrainian)

[16] Educational-professional program "Secondary education: Computer Science " of the first level of higher education for a bachelor's degree in specialty 014 Secondary education by subject specialization 014.09 Computer Science of knowledge 01 Education/Pedagogy. Ishmael, 2017. [Online]. Available:: http://idgu.edu.ua/wp-content/uploads/2018/07/osv.prohr.inform_2017-nova-2.pdf (in Ukrainian)

[17] Educational-professional program 014.09 Secondary education (Computer Science) level of higher education first (bachelor's) degree of higher education bachelor's specialty 014 Secondary education subject specialization 014.09 Secondary education (Computer Science). Rivne, 2019. [Online]. Available: http://rshu.edu.ua/images/osvitni_programi/osv_prog_bak_014_so_informatika_2019.pdf (in Ukrainian)

[18] A.A. Kharkivska, "Improving the quality of higher pedagogical education through the use of the latest information technologies", Problems of engineering and pedagogical education, no. 37, pp. 46-50, 2012.

[19] National doctrine of education development. [Online]. Available: http://zakon4.rada.gov.ua/laws/show/347/2002 (in Ukrainian).

[20] Yu.I. Minhalova, «Information and communication technologies as one of the means of realization of research activity of students of physics and mathematics faculties», Scientific notes of Berdyansk state pedagogical university, Series: Pedagogical sciences, issue. 1, pp. 171-177, 2018 (in Ukrainian).

[21] Yu.I. Minhalova, «Principles of using flexible project management Scrum in research work of students», «Innovative pedagogy», Issue 7, Volume 2, Odessa: PU «Black Sea Research Institute of Economics and Innovation», pp. 79-82, 2018 (in Ukrainian).

[22] Yu.I. Minhalova, «Organization of student research activities in classes on the subject» Fundamentals of Scientific Research», Pedagogy of creative personality formation in higher and secondary schools: Coll. Science.works / [ed.: A.V. Sushchenko (ed.), Etc.], Zaporozhye: CPU, Issue. 61, vol. 2, P. 126-131, 2018 (in Ukrainian).

[23] Yu.I. Minhalova, «Using Google service to support and support student research», Collection of scientific works, Pedagogical sciences / Issue LXXXVIII, Kherson: Kherson State University, pp. 115-119, 2019 (in Ukrainian).

[24] V. Yu. Bykov, V.V. Oliynyk, «Information networks of open learning environment», Postgraduate education in Ukraine, no.1, pp. 54-63, 2008 (in Ukrainian).

[25] V. Yu. Bykov, O. M. Spirin, M. P. Shyshkina, «Corporate information systems to support research and educational activities based on cloud-based services», Problems and prospects for the formation of the national humanitarian and technical elite: Coll. Science. works / ed. L.L. Tovazhnyansky, O.G. Romanovsky, Issue. 43, Part 2, Kharkiv: NTU «KhPI»,P. 93-121, 2015 (in Ukrainian).

[26] Digital science in Horizon 2020, DG Connect, 7 March 2013, 30 p. (in English).

[27] Strategy Report on Research Infrastructures. Roadmap 2010, Luxembourg: Publication Office of the European Union, 80 p., 2011 (in English).

\section{(cC) BY-NC-SA}

ThisworkislicensedunderCreativeCommonsAttribution-NonCommercial-ShareAlike 4.0 InternationalLicense. 